\title{
Accessory mineral constraints on crustal evolution: elemental fingerprints for magma discrimination
}

\author{
E. Bruand ${ }^{1 *}$, M. Fowler ${ }^{2}$, C. Storey $^{2}$, O. Laurent ${ }^{3}$, C. Antoine ${ }^{1}$, \\ M. Guitreau', E. Heilimo ${ }^{4}$, O. Nebel ${ }^{5}$
}

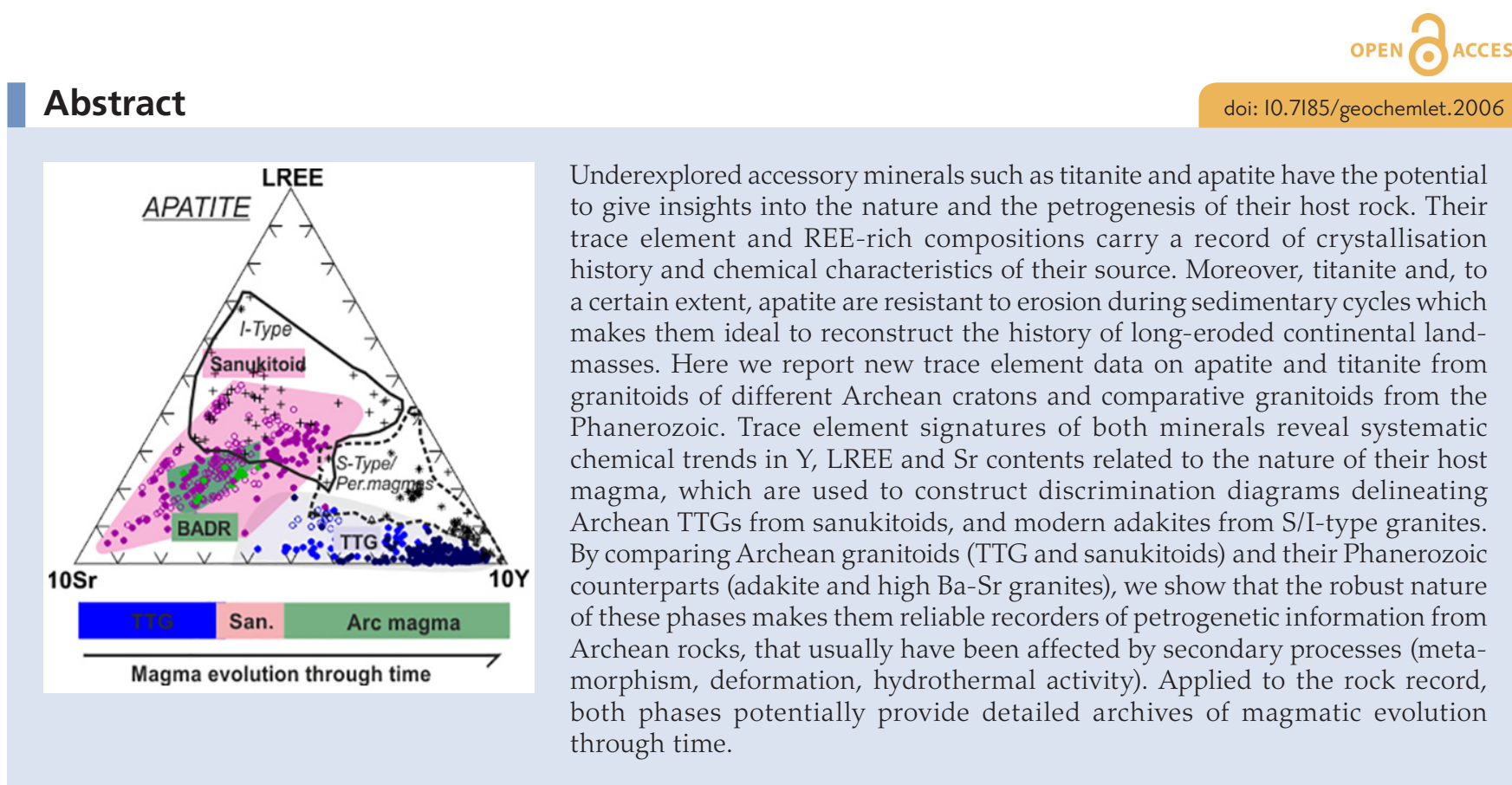

Received 27 August 2019 | Accepted 18 January 2020 | Published 26 February 2020

\section{Introduction}

Rare earth element (REE) bearing minerals have been used widely to date geological events and are prime archives for magmatic petrogenesis. Their ability to incorporate a range of trace elements in addition to REE make them extremely useful to track geological processes. While most studies on accessory minerals have focussed on zircon (e.g., U-Pb, Hf isotopes, $\mathrm{O}$ isotopes, trace elements), the development of more advanced in situ techniques has also facilitated other phases to be dated (e.g., monazite, Kohn and Vervoort, 2008; titanite, Storey et al., 2007), thus providing additional chronological constraints on host rock history. However, despite the impressive number of studies on accessory minerals available today (see Nasdala et al., 2017), knowledge of the behaviour of trace elements within accessory minerals in rocks that make up the continental crust is still limited. The few contributions focussing on less-studied, REE-bearing minerals (e.g., apatite and titanite, Belousova et al., 2001; Chu et al., 2009; Bruand et al., 2014) have shown that trace element concentrations retain considerable information relevant to petrogenesis and provenance, potentially even more than zircon, whose compositional variability in the most common continental igneous rocks (e.g., granitoids, Grimes et al., 2015) is relatively limited. In experimental work focussing on metaluminous compositions, Protwake and Klemme $(2005,2006)$ have suggested that REE and other trace elements are sensitive to melt evolution. Recent publications based on a small number of samples (Bruand et al., 2016, 2017, 2019) have shown that apatite and titanite trace element chemistry combined with $\mathrm{O}$ isotopes are useful tracers of granitoid petrogenesis and therefore have the potential to discriminate the different magmas through time and could provide an opportunity to track the secular evolution of the early Earth and the onset of modern style plate tectonics. For this contribution, we have studied the chemical signatures of accessory minerals in a range of crust-forming granitoids through time, from a relatively hot Archean Earth producing "tonalites-trondjhemites-granodiorites" (TTG)

\footnotetext{
Laboratoire Magmas et Volcans, Campus Universitaire des Cezeaux, 6 avenue Blaise Pascal, 63718 Aubiere, France

School of Earth and Environmental Sciences, University of Portsmouth, PO1 3QL, United Kingdom

Geosciences Environnement Toulouse, Université de Toulouse, 31400 Toulouse, France

Geotalo, Akatemiankatu 1, University of Turku, Finland

School of Earth, Atmosphere and Environment, Monash University, Melbourne, Australia
} 


\section{Continental crust evolution}

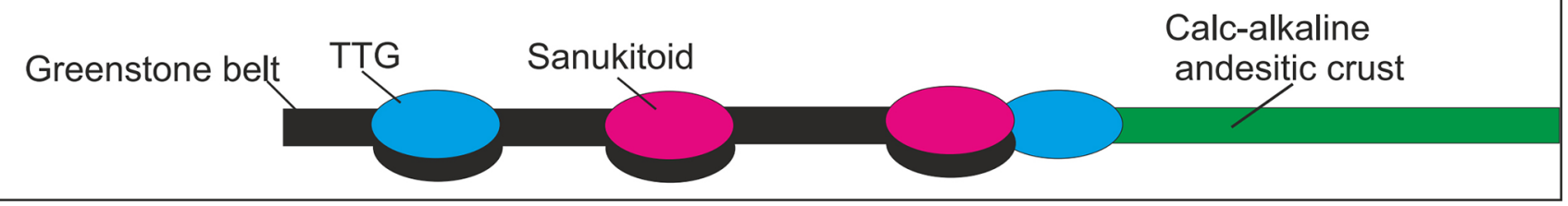

$2.7 \mathrm{Ga}$

Karelia-

Province

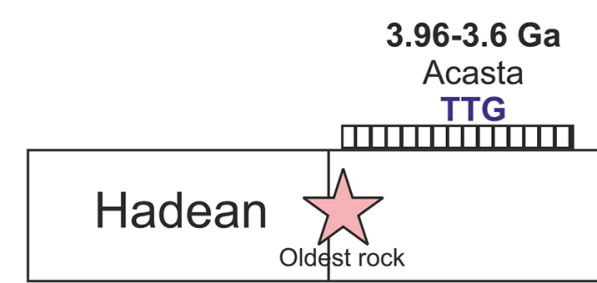

$4.5 \mathrm{Ga}$
2.5-3.5 Ga

Kaapvaal Craton TTG, Sanuk. TTG and Sanuk.
$0.4 \mathrm{Ga}$

High Ba-Sr

Sanuk.-like

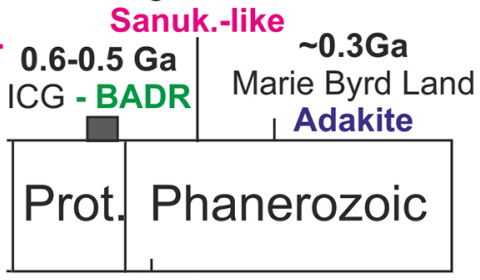

$2.5 \mathrm{Ga} \quad 0.5 \mathrm{Ga}$

Figure 1 Cartoon of continental crust evolution, from TTG (blue) and sanukitoid (pink) in the Archean towards typical arc magma (green) in Proterozoic and Phanerozoic, plus samples studied in this contribution.

toward a cooler modern Earth producing plutonic equivalents of the calc-alkaline series (basalt-andesite-dacite-rhyolite, or BADR), via the Neoarchean - Palaeoproterozoic transition to modern plate tectonics signalled by sanukitoids and related rocks. We demonstrate that their trace element signatures can be used to discriminate between critical magma types and can be robust with respect to metamorphism. We then discuss the causes of consistent differences in accessory mineral chemistry and implications of their robust discrimination for studies of magmatic and crustal evolution through geological times.

\section{Granitoid Samples and their Crustal Evolution Context}

The granitoid record (Fig. 1) has evolved from the Archean to the Phanerozoic, as a reflection of Earth's cooling and evolution of tectono-magmatic processes (see Moyen and Laurent, 2018 and references therein). Granitoids representing newly formed continental crust have hence changed from Archean TTGs, formed by partial melting of mafic crust, via sanukitoids and related rocks in the Neoarchean and Palaeoproterozoic that carry the signature of a nascent mantle wedge, towards granodiorites and granites with arc magma compositions (the plutonic equivalents of BADR). Many fundamental questions remain regarding the geodynamics of the early Earth, the growth of the continental crust and the transition to subduction-driven tectonics, some of which may be addressed with a more complete understanding of timings and proportions of granitoid magma genesis. Here we present new geochemical data on titanite and apatite from granitoids selected from this overall temporal progression; (i) Archean TTG from three different cratons (Slave Province, Karelia and Kaapvaal), (ii) sanukitoids from the Karelia and Kaapvaal cratons, (iii) Neoproterozoic calc-alkaline granitoids from Guernsey (UK Channel Islands) in the Armorican terrane. Studied Archean localities have been affected by metamorphic conditions up to amphibolite facies. In addition to these, we have included likely Phanerozoic equivalents to test the impact of metamorphism on their older counterparts: TTG-like (adakites from Antarctica; Pankhrust et al., 1998) and sanukitoid-like rocks (high Ba-Sr granites from Caledonian Scotland; Fowler and Rollinson, 2012). Detailed sample descriptions, geological settings and whole rock compositions can be found in the Supplementary Information.

\section{Results}

Trace element concentrations obtained by LA-ICPMS on single minerals and related analytical protocols are described in the Supplementary Information. After initial data interrogation using principal component analysis (PCA) on both apatite and titanite datasets, REEs, Y and Sr were found to be most effective for discriminating magma type. These results are presented and discussed below.

Apatite chemistry. Chondrite normalised REE patterns for apatite from all studied samples are plotted on Figure 2a-e. TTG samples (Fig. 2a) are characterised by a systematic depletion in light REE (LREE) relative to heavy REE (HREE; $\mathrm{La}_{N} / \mathrm{Lu}_{\mathrm{N}}$ $<1$ ) usually with a strong negative Eu anomaly (usually Eu/ $\mathrm{Eu}^{*}=0.15-0.8$ ). The most depleted patterns tend to have a less pronounced to absent Eu anomaly and noticeable middle REE (MREE) fractionation from HREE. Adakite (TTG-like) apatite crystals (Fig. 2b) have a relatively flat LREE pattern ( $\mathrm{La}_{\mathrm{N}} /$ $\left.\mathrm{Sm}_{\mathrm{N}}=0.5-1.8\right)$ with slightly lower $\operatorname{HREE}\left(\mathrm{La}_{N} / \mathrm{Lu}_{\mathrm{N}}=1.5-4\right)$ and a negative Eu anomaly $\left(\mathrm{Eu} / \mathrm{Eu}^{*}=0.3-0.4\right)$. Typical BADR REE patterns (Fig. 2c) show higher LREE content with strong enrichment compared to the HREE $\left(\mathrm{La}_{N} / \mathrm{Lu}_{N}>15\right)$, with moderate negative $\mathrm{Eu}$ anomalies $\left(\mathrm{Eu} / \mathrm{Eu}^{*} \approx 0.5\right)$. Similarly, sanukitoids and high Ba-Sr granite REE patterns (Fig. 2d,e) reveal a general enrichment in LREE relative to HREE $\left(\mathrm{La}_{\mathrm{N}} / \mathrm{Lu}_{\mathrm{N}}=10-100\right)$ usually with moderate negative Eu anomalies $\left(\mathrm{Eu} / \mathrm{Eu}^{*} \approx 0.4-0.8\right)$. In the high Ba-Sr group, the most mafic samples often lack Eu anomalies.

Following the PCA procedure, a $10^{*} \mathrm{Sr}-\mathrm{LREE}-10^{*} \mathrm{Y}$ discrimination diagram was constructed (Fig. 3a). Apatite from TTG and TTG-like granitoids are clearly distinguishable from other granitoid types, defining a distinct cluster towards the $10 *$ Y corner and having Sr contents ranging between 150 and $430 \mu \mathrm{g} / \mathrm{g}$ (Table S-3). On the other hand, sanukitoids, sanukitoid-like and BADR samples are characterised by higher LREE and Sr contents (up to $1000 \mu \mathrm{g} / \mathrm{g}$ ) and thus form a separate field towards that baseline. Similarly, a $\mathrm{La}_{N} / \mathrm{Sm}_{\mathrm{N}}$ versus $\mathrm{Y}$ diagram (Fig. 4a) highlights a strong compositional difference. TTG and TTG-like apatite grains are Y-rich (up to 

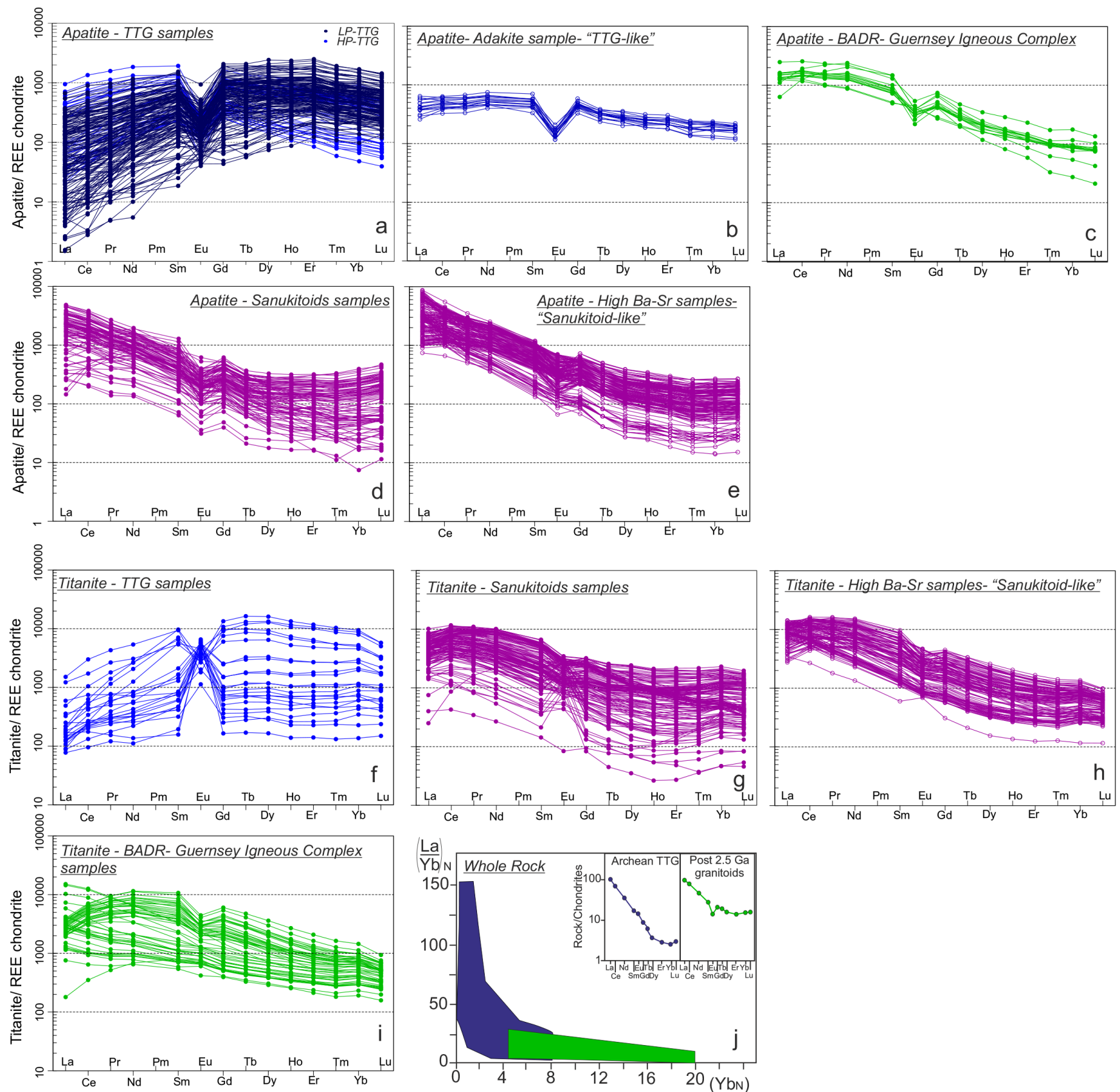

Figure 2 Chondrite normalised REE patterns for apatite (a-e) and titanite (f-i). Diagram j represents La/Yb vs. Yb values normalised to chondrite for whole rock data, modified after Moyen and Martin (2012). Green and blue fields correspond to post $2.5 \mathrm{Ga}$ granitoids and TTG, respectively.

approximately $4600 \mu \mathrm{g} / \mathrm{g})$ with low La $(<300 \mu \mathrm{g} / \mathrm{g})$, whereas sanukitoid, high Ba-Sr granite and BADR apatite grains define a field poor in $Y(<1000 \mu \mathrm{g} / \mathrm{g})$ and with La up to approximately $2800 \mu \mathrm{g} / \mathrm{g}$.

Titanite chemistry. REE patterns of titanite from the studied samples are presented in Figure $2 \mathrm{f}-\mathrm{i}$, although titanite is not present in all studied samples (see Supplementary Information). There are many similarities with the patterns for apatite (Fig. 2a-e). Titanite grains from one TTG sample (Fig. 2f) are characterised by pronounced LREE depletion relative to HREE (usually $\mathrm{La}_{N} / \mathrm{Lu}_{\mathrm{N}}<0.5$ ). In contrast with apatite, the patterns have variable, usually large $\mathrm{Eu}$ anomalies $\left(\mathrm{Eu} / \mathrm{Eu}^{*}=0.2-40\right)$, generally negative for those with higher total REE, positive for lower total REE. Titanite from sanukitoids and high Ba-Sr granites (Fig. 2g,h) show strong enrichment of LREE relative to HREE $\left(\mathrm{La}_{N} / \mathrm{Lu}_{N} \approx 3-45\right)$, usually with a convex upward LREE section and a noticeable negative Eu anomaly. A few sanukitoid titanites in each of the samples studied have steep downward LREE slopes and/or a positive Eu anomaly (Fig. 2g). The BADR REE patterns (Fig. 2i) are closely comparable with the high Ba-Sr samples, but can be separated into two groups that are sample specific. Sample EG-07 titanite crystals have convex upward LREE $\left(\mathrm{La}_{N} / \mathrm{Sm}_{\mathrm{N}}=0.4-0.9\right)$ and a negative $\mathrm{Eu}$ anomaly $\left(\mathrm{Eu} / \mathrm{Eu}^{*} \approx 0.6-0.7\right)$ whereas one from sample BD-02 has continually decreasing LREE $\left(\mathrm{La}_{\mathrm{N}} / \mathrm{Sm}_{\mathrm{N}}>1\right)$ with no Eu anomaly (Fig. 2i, Table S-3 in Supplementary Information).

Using a similar trivariate diagram to apatite (Fig. 3b, but note the different $\mathrm{Sr}$ multiplier accounting for lower Sr contents in titanite), TTG titanite compositions may be discriminated from all other samples. Titanite from TTG define an end member with high Y (up to $24000 \mu \mathrm{g} / \mathrm{g}$ ) and low Sr (usually $<20 \mu \mathrm{g} / \mathrm{g}$ ) and LREE (e.g., usually La $<150 \mu \mathrm{g} / \mathrm{g}$ ) contents relative to sanukitoids and BADR samples ( $\mathrm{Y}$ and La contents are up to $4000 \mu \mathrm{g} / \mathrm{g}$; Sr $>40 \mu \mathrm{g} / \mathrm{g}$ ). 


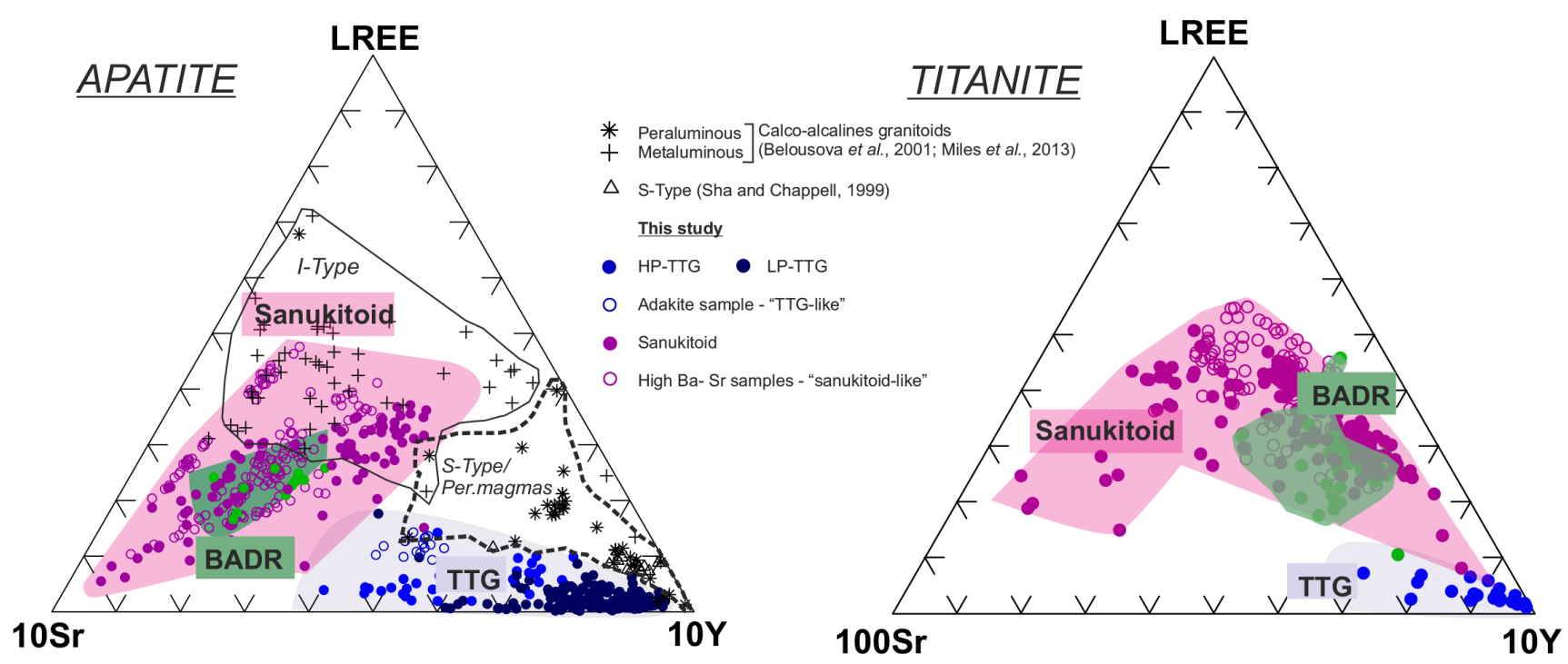

Figure 3 Ternary discrimination diagrams; $10 *$ Sr-LREE-10*Y for apatite and 100*Sr-LREE-10*Y for titanite.
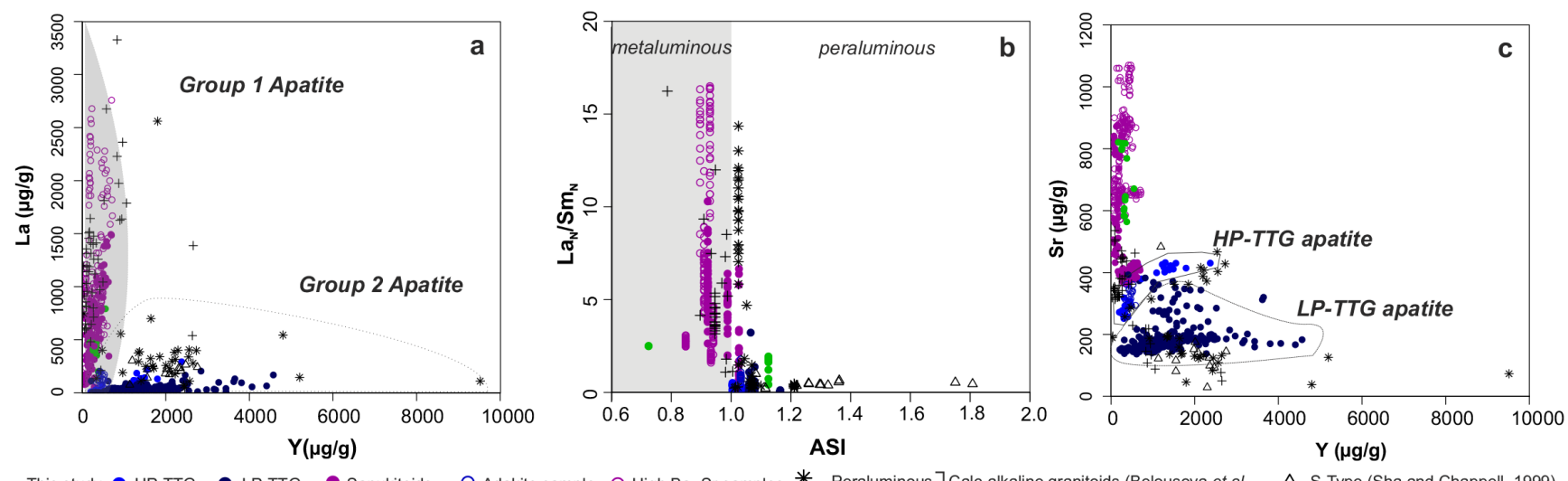

This study $\bullet$ HP-TT

- LP-TTG - Sanukitoids O Adakite sa

"TTG-like"
"sanukitoid-like"
+ Metaluminous

Figure 4 Apatite compositions: (a) La vs. Y diagram discriminating 2 groups of apatite, (b) La $/ \mathrm{Sm}_{N}$ vs. ASI (nAl/((nCa-3.33*nP) + nNa $+\mathrm{nK})$ ), discriminating peraluminous from metaluminous compositions and (c) Sr vs. Y, discriminating apatite from HP- and LP-TTG magmas.

\section{Discussion}

The temporal evolution of granitoids has been well established (Fig. 1, see also Moyen and Martin, 2012 for review). Most TTGs can be discriminated on the basis of several whole rock chemical indicators, the most prevalent of which is stronger HREE depletion (Fig. 2j). The present study has also shown systematic differences in TTG apatite and TTG titanite compositions relative to sanukitoids and post-Archean granitoids (Figs. 2, 3), in particular higher $Y$ and HREE contents with low $\mathrm{La}_{\mathrm{N}} / \mathrm{Sm}_{\mathrm{N}}$ ratio (Figs. 2, 4a). Intriguingly, this is completely opposite to the whole rock signatures (Fig. $2 \mathrm{j}$ ). In the following text, we attempt to rationalise such observations in terms of possible controls on apatite and titanite chemistry, and in the light of current literature.

Effects of metamorphism and/or deformation. Because Archean rocks may have suffered metamorphism and/ or deformation, there is the obvious possibility that accessory mineral chemistry has been modified and records metamorphic/hydrothermal rather than igneous processes. The studies available on the impact of metamorphism and hydrothermalism on apatite and titanite are limited (e.g., Broska et al., 2007) and often describe lithologies and/or whole rock compositions (metapelites or orthogneisses) that are very different from our samples (e.g., Bea and Montero, 1999; Garber et al.,
2017). Therefore, in order to test the robustness of apatite and titanite magmatic signatures, we have analysed apatite and titanite from Phanerozoic equivalents of TTG (adakite; Fig. 2b) and sanukitoid (high Ba-Sr granites; Fig. 2e,h), unaffected by any metamorphic event. Their chondrite normalised REE patterns correspond closely to the Archean equivalents (Fig. $2 \mathrm{a}, \mathrm{d}, \mathrm{g})$ and overlap the relevant fields on the discrimination diagrams above (Figs. 3, 4a).

A few TTG apatite patterns show extreme depletion in LREE with no Eu anomaly (Fig 2a). This can be explained petrographically, by the observed association of secondary allanite and apatite, which form at the expense of primary REE-bearing phases (Fig. S-1). The highly LREE-depleted group in our samples, is therefore interpreted to have formed under high grade metamorphic conditions and are characterised by lower $\mathrm{La}_{N} / \mathrm{Sm}_{\mathrm{N}}$ but retains original HREE signatures.

Effects of whole rock composition. The systematic chemical differences between the accessory mineral groups studied here, from different types of granitoid, strongly suggest that bulk rock character exerts strong control on the trace element composition of accessory minerals.

1. The influence of whole rock $\mathrm{SiO}_{2}$. Partition coefficient studies have shown that incorporation of REE in apatite and titanite increases with $\mathrm{SiO}_{2}$ of the magma (Prowatke and 
Klemme, 2005, 2006). TTGs studied herein vary between 65 wt. $\%$ and 74 wt. $\% \mathrm{SiO}_{2}$, the other granitoids range between 53 and 77 wt. \%. Within the former, apatite and titanite total REE contents do not systematically increase with $\left[\mathrm{SiO}_{2}\right]$ of the melt (Table S-3, Supplementary Information). Furthermore, sanukitoid or BADR samples with similar $\mathrm{SiO}_{2 W R}$ have apatite and titanite characterised by comparatively higher LREE and lower HREE. Such systematic differences are therefore not controlled simply by silica content.

2. The influence of alumina saturation index (ASI) The striking dichotomy in the TTG between LREE depletion in the accessory minerals and LREE enrichment in whole rocks suggests that another LREE-bearing phase is required for mass balance. Likely contenders would be allanite and monazite, but since these are also common in many other granitoid types, this is unlikely to be the sole explanation.

Figure 4a includes literature data, and highlights the presence of two distinct groups of apatite that are strongly dependent on ASI. ASI $<1$ samples (metaluminous) correspond to our sanukitoids-BADR apatites (Group 1), whereas peraluminous samples (ASI > 1) have a comparable chemical signature to TTG apatite grains (low LREE and high HREE-Y, Group 2). This corroborates previous studies on apatite (Harrison and Watson, 1984; Pichavant et al., 1992) and monazite (Montel, 1986) solubilities, which suggest that apatite solubility increases with ASI and (to a lesser extent) with $\mathrm{SiO}_{2}$ in metaluminous magmas. Conversely, Montel (1986) has shown that monazite solubility decreases as ASI increases. This is also consistent with the presence of "remaining" primary monazite surrounded by secondary allanite and apatite identified on the studied Acasta samples (Supplementary Information). It should be noted that monazite solubity can also be influenced by other factors (e.g., P content in the melt; Skora and Blundy, 2012). In summary, our dataset demonstrates that in peraluminous compositions early monazite will strongly partition LREE with the remaining melt relatively enriched in HREE and Y, which will be incorporated by later apatite and titanite. These conclusions were also reached in previous work on Phanerozoic granitoids (e.g., Chu et al., 2009).

Interestingly, apatites from two metaluminous samples are Y-rich and LREE-poor (Fig. 4a), which is inconsistent with the general trend. These exceptions have the highest $\mathrm{SiO}_{2}$ content (>73 wt. \%), a phenomenon also described by Sha and Chappell (1999). High melt $\mathrm{SiO}_{2}$ content increases apatite solubility (Harrison and Watson, 1984) and therefore delays its saturation. Consequently, apatite may grow late, allowing early LREE phases (monazite and/or allanite) to incorporate most of the LREE.

3. Other variables. We have shown above that aluminosity and consequent timing of mineral saturation is a first order control on accessory mineral chemistry. However, our TTG apatite compositions have systematically even lower LREE concentrations than published apatite data for peraluminous rocks (Fig. 4a), so other variables must also be important. For example, previous authors have inferred that differences in magmatic apatite composition could be related to magma $\mathrm{fO}_{2}$ (Sha and Chappell, 1999; Belousova et al., 2001). It remains unclear whether this is linked to the nature of the TTG source (e.g., composition such as high $\mathrm{Na}_{2} \mathrm{O}$ and low $\mathrm{REE}$ content compared to other granitoids, $\mathrm{fO}_{2}$, temperature, $\mathrm{H}_{2} \mathrm{O}$-saturated or undersaturated melting) or is another effect of co-crystallising accessory phases. Experimental constraints are currently lacking.

4. The significance of Sr. Previous work (e.g., Halla et al., 2009; Moyen, 2011) has distinguished high pressure TTG, corresponding to a deep source in equilibrium with garnet and rutile but no plagioclase, from low pressure TTG consistent with residual plagioclase. As a direct consequence of residual mineralogy, HP-TTG have low HREE, Nb and Ta and high $\mathrm{Sr}$ whereas LP-TTG show the opposite signature for comparable bulk compositions (e.g., Moyen and Martin, 2012). Previous authors (Belousova et al., 2001; Jennings et al., 2011; Bruand et al., 2014) have shown a strong correlation between $\mathrm{Sr}$ in apatite and in the corresponding whole rock. Our data sit on this previously reported correlation. Accordingly, in our apatite dataset, two TTG and our adakite samples that have typical HP-TTG signatures have systematically higher Sr concentrations than the others that have LP-TTG signatures (Fig. 4c). Figure 4c also shows that the HP-TTG apatite analyses have lower $Y$ (and by analogy, HREE). All these observations confirm that apatite Sr content can allow discrimination between HP and LP-TTG. Interestingly, correlation between unusually high Sr content of monazite and HP conditions has also been previously reported in the Bohemian Massif peraluminous rocks (Finger and Krenn, 2007).

Implications for crustal evolution research. The preservation of magmatic trace element signatures in apatite and titanite, from metamorphosed terranes such as those of Archean age, provides a useful method to reconstruct ancient magmatic history. For example, in this study, we demonstrate that accessory minerals of late Archean granitoids (sanukitoids) are different from Archean TTGs. Such differences reflect whole rock compositions which themselves reflect petrogenetic processes. Thus, the different petrogeneses of TTGs and sanukitoids (early subduction or "drip tectonics"; Nebel et al., 2018) are reflected by accesssory mineral chemistry. Therefore detailed investigation of the apatite and titanite mineral chemical archive could tightly constrain the change in geodynamics at the end of the Archean. Finally, our data reveal an efficient distinction of parental magma types based on REE-Sr-Y alone which further encourages application to the detrital mineral record. Voluminous data exist from zircons, but the results described above promise much closer constraints on parent rock identity, thus providing vital access to the primary history of eroded terranes and helping to reconstruct the historical evolution of continental crust from the early Earth to the present day.

\section{Acknowledgements}

We are grateful to Stuart Kearns and J.-L. Devidal for microanalytical analyses, to Geoff Long for amazing technical support. This work was supported by the Natural Environment Research Council (grant NE/I025573/1) and by the French Government Laboratory of Excellence initiative ${ }^{\circ}$ ANR-10-LABX-0006. This is Laboratory of Excellence ClerVolc contribution number 387. We deeply thank the editor H. Marschall and two anonymous reviewers for their input.

Editor: Horst R. Marschall

\section{Additional Information}

Supplementary Information accompanies this letter at http:// www.geochemicalperspectivesletters.org/article2006.

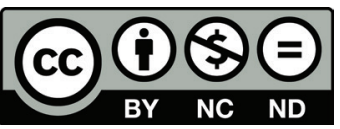

This work is distributed under the Creative Commons Attribution Non-Commercial No-Derivatives 4.0 License, which permits unrestricted distribution provided the original author and source are credited. The material may not be adapted (remixed, transformed or built upon) or used for commercial purposes without 
written permission from the author. Additional information is available at http://www.geochemicalperspectivesletters.org/ copyright-and-permissions.

Cite this letter as: Bruand, E., Fowler, M., Storey, C., Laurent, O., Antoine, C., Guitreau, M., Heilimo, E., Nebel, O. (2020) Accessory mineral constraints on crustal evolution: elemental fingerprints for magma discrimination. Geochem. Persp. Let. 13, 7-12.

\section{References}

BeA, F., Montero, P. (1999) Behavior of accessory phases and redistribution of Zr, REE, Y, Th, and U during metamorphism and partial melting of metapelites in the lower crust: An example from the Kinzigite Formation of Ivrea-Verbano, NW Italy. Geochimica et Cosmochimica Acta 63, 1133-1153.

Belousova, E.A., Walters, S., Griffin, W.L., O’Reilly, S.Y. (2001) Trace-element signatures of apatites in granitoids from the Mt Isa Inlier, Northwestern Queensland. Australian Journal of Earth Sciences 48, 603-619.

Broska, I., Harlov, D., Tropper, P., Siman, P. (2007) Formation of magmatic titanite and titanite-ilmenite phase relations during granite alteration in the Tribe?? Mountains, Western Carpathians, Slovakia. Lithos 95, 58-71.

Bruand, E., Storey, C., Fowler, M. (2014) Accessory mineral chemistry of high Ba-Sr granites from Northern Scotland: Constraints on petrogenesis and records of whole-rock Signature. Journal of Petrology 55, $1619-1651$

BRUAND, E., Storey, C., Fowler, M. (2016) An apatite for progress: Inclusions in zircon and titanite constrain petrogenesis and provenance. Geology 44, 91-94

Bruand, E., Fowler, M., Storey, C., Darling, J. (2017) Apatite trace element and isotope applications to petrogenesis and provenance. American Mineralogist 102, 75-84

Bruand, E., Storey, C., Fowler, M., Heilimo, E. (2019) Oxygen isotopes in titanite and apatite, and their potential for crustal evolution research Geochimica et Cosmochimica Acta 255, 144-162.

Chu, M.F., Wang, K.L., Griffin, W.L., Chung, S-L, O’Reilly, S. PEARSON, N.J., IIZUKA, Y. (2009) Apatite composition: Tracing petrogenetic processes in Transhimalayan granitoids. Journal of Petrology 50, 1829-1855.

Finger, F., KRENN, E. (2007) Three metamorphic monazite generations in a high-pressure rock from the Bohemian Massif and the potentially important role of apatite in stimulating polyphase monazite growth along a PT loop. Lithos 95, 103-115.

Fowler, M., Rollinson, H. (2012) Phanerozoic sanukitoids from Caledonian Scotland: Implications for Archean subduction. Geology 40, 1079-1082.

Garber, J.M., Hacker, B.R., Kylander-Clark, A.R.C., Stearns, M., SEWARD, G. (2017) Controls on Trace Element Uptake in Metamorphic Titanite: Implications for Petrochronology. Journal of Petrology 58, 1031-1058

Grimes, C.B., Wooden, J.L., Cheadle, M.J., John, B.E. (2015) “ Fingerprinting " tectono - magmatic provenance using trace elements in igneous zircon. Contributions to Mineralology and Petrology 170, 1-26.

Halla, J., van Hunen, J., Heilimo, E., HöltTä, P. (2009) Geochemical and numerical constraints on Neoarchean plate tectonics. Precambrian Research 174, 155-162.

HARRISON, T.M., WATSON, E.B. (1984) The behavior of apatite during crustal anatexis: Equilibrium and kinetic considerations. Geochimica et Cosmochimica Acta 48, 1467-1477.

Jennings, E.S., Marschall, H.R., Hawkesworth, C.J., Storey, C.D.; (2011) Characterization of magma from inclusions in zircon: Apatite and biotite work well, feldspar less so. Geology 39, 863-866.

KOHN, M.J., VERVOORT, J.D. (2008) U-Th-Pb dating of monazite by single-collector ICP-MS: Pitfalls and potential. Geochemistry, Geophysics, Geosystems 9, 1-16

Montel, J.M. (1986) Experimental determination of the solubility of Ce-monazite in $\mathrm{SiO} 2-\mathrm{A} 12 \mathrm{O} 3-\mathrm{K} 2 \mathrm{O}-\mathrm{Na} 2 \mathrm{O}$ melts at $800^{\circ} \mathrm{C}, 2 \mathrm{kbar}$, under $\mathrm{H} 2 \mathrm{O}$-saturated conditions. Geology 14, 659-662.

MoYen, J. (2011) The composite Archaean grey gneisses : Petrological significance, and evidence for a non-unique tectonic setting for Archaean crustal growth. Lithos 123, 21-36.
Moyen, J., Laurent, O. (2018) Archaean tectonic systems: A view from igneous rocks. Lithos 303, 99-125.

MOYEN, J., MARTIN, H. (2012) Forty years of TTG research. Lithos 148, 312-336.

Nasdala, L., Broska, I., Harlov, D.E., Macdonald, R. (2017) Recent progress in the study of accessory minerals. Mineralogy and Petrology 102, 431-433.

Nebel, O., Capitanio, F.A., Moyen, J.-F., Weinberg, R.F., Clos, F., Nebel-Jacobsen, Y.J., CAWOOD, P. (2018) When crust comes of age : on the chemical evolution of Archaean, felsic continental crust by crustal drip tectonics. Philosophical Transactions of the Royal Society A: Mathematical, Physical and Engineering Sciences 376, doi: 10.1098/ rsta.2018.0103.

Pankhrust, R.J., Weaver, S.D., BradshaW, J.D., Storey, B.C., Ireland, T.R. (1998) Geochronology and geochemistry of pre-Jurassic superterranes in Marie Byrd Land, Antarctica. Journal of Geophysical Research 103, 2529-2547.

Pichavant, M., Montel, J.M., LindA, R. (1992) Apatite solubility in peraluminous liquids: Experimental data and an extension of the Harrison-Watson model. Geochemica et Cosmochimica Acta 56, 3855-3861.

ProwatKe, S., KLemme, S. (2005) Rare earth element partitioning between titanite and silicate melts: Henry's law revisited. Geochimica et Cosmochimica Acta 70, 4997-5012.

ProwATKe, S., KLEMME, S. (2006) Trace element partitioning between apatite and silicate melts. Geochimica et Cosmochimica Acta 70, 4513-4527.

SHA, L.-K., Chappell, B.W. (1999) Apatite chemical composition, determined by electron microprobe and laser-ablation inductively coupled plasma mass spectrometry, as a probe into granite petrogenesis. Geochimica et Cosmochimica Acta 63, 3861-3881.

SKORA, S., BLUNDY, J. (2012) Monazite solubility in hydrous silicic melts at high pressure conditions relevant to subduction zone metamorphism. Earth and Planetary Science Letters 322, 104-114.

Storey, C.D., Smith, M.P., Jeffries, T.E. (2007) In situ LA-ICP-MS U-Pb dating of metavolcanics of Norrbotten, Sweden: Records of extended geological histories in complex titanite grains. Chemical Geology 240, 163-181. 